\title{
Analisis Performansi Sistem Jaringan Femtocell 5G Berbasis Simulasi
}

\author{
Uri Ramadhani ${ }^{1}$, Werry Febrianti ${ }^{2}$, Heriansyah Najemi ${ }^{3}$ \\ ${ }^{1,3}$ Program Studi Teknik Elektro, Jurusan Teknologi Produksi dan Industri, Institut Teknologi Sumatera, Indonesia \\ ${ }^{2}$ Program Studi Matematika, Jurusan Sains, Institut Teknologi Sumatera, Indonesia \\ uri.ramadhanidel.itera.ac.id ${ }^{1}$ \\ werry.febrianti@ma.itera.ac.id ${ }^{2}$ \\ heriansyah.najemidel.itera.ac.id ${ }^{3}$
}

Intisari-Dalam beberapa dekade terakhir, perkembangan teknologi telekomunikasi telah berevolusi secara signifikan. Teknologi 4G yang mulai berjalan secara komersial sejak tahun 2013 di Indonesia akan segera tergantikan dengan teknologi 5G yang telah ada di ambang pintu. Dalam penelitian ini, kami mempelajari skenario dimensi jaringan yang sesuai untuk mencapai datarate yang ditargetkan sesuai dengan standar $5 \mathrm{G}$ pada suatu lokasi dengan kepadatan pengguna yang cukup tinggi. Penelitian ini difokuskan pada jaringan femtocell yang merupakan small base station (akses poin) yang didesain untuk penggunaan indoor dengan konsumsi daya yang rendah. Dalam penelitian ini, digunakan tiga skenario antena (Multi-Input Multi-Output) MIMO yang berbeda. Dari hasil simulasi diperoleh bahwa dengan konfigurasi MIMO 16X16, sistem jaringan telah mampu menyediakan datarate sebesar 1Gbps untuk semua pengguna, dan menunjukkan hasil yang paling baik dibandingkan konfigurasi MIMO 4X4 dan MIMO 8X8.

Kata kunci--- 5G, femtocell, MIMO, datarate

Abstract-In recent decades, the development of telecommunications technology has evolved significantly. 4G technology that began running commercially since 2013 in Indonesia will soon be replaced with 5G technology. In this research, we study the appropriate network dimension scenarios to achieve the targeted datarate according to the 5G standard at a location with a fairly high user density. This research is focused on the femtocell network which is a small base station (access point), designed for indoor use with low power consumption. In this study, three different MIMO (Multi-Input Multi-Output) antenna scenarios are used. From the simulation results, it is obtained that with the 16X16 MIMO configuration, the network system has been able to provide a datarate of 1 Gbps for all users, and shows the best results compared to the MIMO 4X4 and MIMO 8X8 configurations.

Keywords---5G, femtocell, MIMO, datarate

\section{PENDAHULUAN}

Saat ini persiapan menghadapi diterapkannya teknologi $5 \mathrm{G}$ tengah gencar dilakukan oleh beberapa konsorsium, seperti METIS (Mobile and wireless communications Enablers for Twenty-twenty (2020) Information Society) dan 5GNOW, yang merupakan gabungan dari akademisi, industri, dan regulator untuk menemukan teknologi yang tepat untuk memenuhi standar teknologi 5G. Selain datarate yang digadang mampu mencapai $10 \mathrm{~GB} / \mathrm{s}$, teknologi $5 \mathrm{G}$ juga memungkinkan adanya komputasi yang menyatu dengan berbagai perangkat sehingga dapat mewujudkan skenario jaringan Internet of Things (IoT). Berdasarkan fakta di atas, untuk dapat turut serta mempersiapkan diri dalam menyambut generasi $5 \mathrm{G}$, diperlukan adanya studi awal untuk mengkaji penerapan teknologi 5G, khususnya di daerah dengan kepadatan penduduk yang tinggi. Pada penelitian ini kami melakukan analisis skenario jaringan femtocell yang dapat memenuhi karakteristik standar teknologi komunikasi seluler bebasis $5 \mathrm{G}$.

\section{TINJAUAN PUSTAKA}

A. Elemen Desain Teknologi $5 G$

Standar teknologi 5G mempunyai target untuk mencapai datarate minimal sepuluh kali lebih tinggi dari data rate saat ini. Trafik seluler diprediksi akan meningkat 1000 kali lebih banyak dibandingkan pada tahun 2010, dan menurut Theodore Rappaport dari pusat riset nirkabel New York University [1], teknologi $4 \mathrm{G}$ saat ini tidak akan mampu mengakomodasi lonjakan trafik tersebut. 
Ada sebuah modifikasi dari teori Shannon yang direncanakan untuk memenuhi meningkatnya permintaan trafik ini [2]:

$C_{\text {sum }}=\sum_{\text {Networks Channels }} \sum_{i} \log _{2}\left(1+\frac{P_{i}}{N_{P}}\right)$

Di mana $i$ adalah channel ke- $i$, B adalah bandwidth, $\mathrm{P}$ adalah daya sinyal, dan $\mathrm{N}$ adalah daya noise.

Beberapa karakteristik teknologi $5 \mathrm{G}$ yang telah didiskusikan oleh berbagai konsorsium akan dijabarkan sebagai berikut.

\section{1) Spektrum}

Saat ini spektrum frekuensi di bawah Gigahertz tidak lagi memungkinkan untuk digunakan karena sudah banyak digunakan untuk komunikasi seluler, televisi, dan radio. Oleh karenanya, dibutuhkan ekspansi ke spektrum yang lebih tinggi, mulai dari $3 \mathrm{GHz}$ bahkan memungkinkan di atas $30 \mathrm{GHz}$ (millimeter wave) [2]. Dengan menggunakan spektrum frekuensi yang masih banyak tersedia, bandwidth sistem yang ditawarkan pun akan semakin besar. Namun tantangan dari penggunaan millimeter wave ini adalah kerentanan terhadap redaman hujan akibat panjang gelombang yang sangat kecil. Untuk mengatasi hal ini, penambahan daya sinyal perlu dilakukan.

\section{2) Beamforming}

Untuk memenuhi standar karakteristik teknologi $5 \mathrm{G}$, sistem jaringan harus mampu menyediakan datarate yang tinggi kepada pengguna dan kapasitas sistem. Beamforming adalah suatu teknik yang dapat mengatasi tantangan tersebut dengan mengarahkan sinyal transmisi dari sejumlah $\mathrm{N}$ antena susunan kepada pengguna [3].

\section{Massive Multi-Input Multi-Output}

(MIMO) dapat dipandang sebagai suatu bentuk beamforming, dengan sejumlah elemen antena pada base station dan terminal pengguna. Antena MIMO terdiri dari banyak elemen antena yang dapat membentuk pola radiasi dan mengarahkan sinyal transmisi ke arah spesifik. Dengan melakukan hal ini, efisiensi channel dan data rate dapat ditingkatkan. Jika spektrum frekuensi tinggi dan gelombang millimeter digunakan dalam sistem jaringan 5G, maka dimensi antena dapat diperkecil hingga mencapai satuan sentimeter, sehingga antena massive MIMO yang terdiri dari puluhan hingga ratusan antena akan sangat memungkinkan untuk diintegrasikan ke berbagai perangkat.

Base station akan secara efektif mengumpulkan Channel State Information (CSI) antara setiap elemen antena dan terminal pengguna. Amplitude relatif dan pergerseran fasa akan diaplikasikan untuk mengarahkan sinyal pada pengguna yang spesifik dan secara bersamaan meminimalisir interferensi dari sinyal pengguna lainnya. Beberapa metode pemrosesan sinyal yang dapat digunakan pada Massisve MIMO adalah Maximum Ratio (MR), Zero Forcing (ZF) [4], dan Minimum Mean Square Error (MMSE).

\section{3) Arsitektur Jaringan Heterogen}

Saat ini jaringan komunikasi yang ada dapat dikatakan telah heterogen, seperti adanya jaringan komunikasi Wi-Fi dan jaringan macro cell di tempat yang sama. Pada teknologi 5G, jumlah jenis jarangan akan semakin beragam dengan adanya komunikasi Device-to-Device yang memungkinkan terjadinya komunikasi antar perangkat secara langsung tanpa melalui base station. Oleh karena itu, kemampuan untuk berkomunikasi antar platform yang berbeda menjadi sangat penting pada standar teknologi 5G.

\section{B. Femtocell}

Femtocell dikenal sebagai solusi yang efisien dalam menyediakan layanan komunikasi nirkabel di dalam ruangan. Dengan ukuran base station yang cukup kecil atau disebut akses poin, maka pembiayaan untuk femtocell jauh lebih murah ketimbang pembangunan jaringan microcell. Dengan jangkauan layanan 10 sampai 50 meter, femtocell dapat melayani pengguna dengan daya rendah dan kapasitas yang tinggi [5].

Metode akses femtocell berhubungan dengan kondisi lingkungan dan model bisnis. Pada Closed Subscriber Group (CSG) hanya pengguna tertentu yang telah terdaftar dapat mengakses layanan, sedangkan pada Open Subscriber Group (OSG) femtocell dapat diakses oleh semua pengguna. Pada mode akses hybrid, beberapa femtocell dapat melayani pengguna yang tidak terdaftar. Mode 
akses femtocell ini akan berpengaruh pada penentuan jumlah femtocell untuk suatu cakupan area. Evaluasi terhadap jaringan femtocell pada penelitian ini akan dilakukan melalui pengukuran Signal to Interference Noise Ratio (SINR) dan datarate. Terlebih dahulu, daya yang diterima pengguna diperoleh dengan perhitungan link budget [6]:

$P_{r}=P_{t}+$ Gain - Cable loss - Path loss -

\section{Interference margin}

Di mana $P_{r}$ adalah daya terima, $P_{t}$ adalah daya kirim, Gain adalah penguatan yang diperoleh dari antena (beamforming), Cable loss adalah redaman akibat saluran transmisi, Path loss adalah redaman menurut model Okumura-Hatta untuk daerah perkotaan., serta Interference margin adalah penguatan daya untuk mengatasi interferensi.

Kemudian SINR dapat diperoleh melalui [6]:

$\operatorname{SINR}(d B)=P_{r}-$ Intereference - Noise

Dengan mengetahui SINR, aktual data rate dapat diperoleh melalui kalkulasi berikut [6]:

Data rate $=$ Bandwidth sistem $x \log _{2}(1+$ SINR)

\section{METODOLOGI PENELITIAN}

Metode yang digunakan dalam penelitian ini menggunakan pendekatan kuantitatif berdasarkan pengukuran dari hasil simulasi. Langkah-langkah yang harus dilakukan dalam penelitian ini adalah penentuan rumusan masalah yaitu untuk mendapatkan skenario jaringan femtocell 5G yang cocok untuk diterapkan.

Kemudian dilanjutkan dengan studi literatur untuk memilih solusi yang tepat untuk menyelesaikan masalah. Jaringan femtocell akan dibangun pada simulasi komputer berdasarkan data awal yang dibutuhkan oleh pangguna, dan kemudian pengumpulan datarate diperoleh pengguna. Pada penelitian ini, daerah yang digunakan sebagai lokasi untuk simulasi sistem adalah lingkungan di sekitar kampus Institut Teknologi Sumatera (ITERA), mengingat peningkatan jumlah mahasiswa yang telah mencapai lebih dari lima ribu orang pada saat ini sehingga sangat representatif untuk mewakili daerah dengan densitas pengguna layanan komunikasi seluler yang tinggi.

\section{A. Jumlah jaringan seluler}

Skenario jumlah jaringan tergantung pada cakupan luas daerah dan traffic data yang dibutuhkan. Berdasarkan master plan pengembangan ITERA, pada tahun 2037 diharapkan akan ada 37360 jumlah pengguna dan $401023 \mathrm{~m} 2$.

Menurut laporan Ericsson [7], permintaan traffic data rata-rata per bulan per pengguna adalah 10 GB dengan traffic puncak 8 jam per hari. Oleh karena itu, permintaan lalu lintas harian diperkirakan 3,46 Mbps per pengguna. Kami menggunakan efisiensi spektral dalam ruangan $6,6 \mathrm{bps} / \mathrm{Hz}$ dan spektrum $20 \mathrm{MHz}$ untuk femtocell base station [8]. Jangkauan layanan femtocell adalah $25 \mathrm{~m}$, dan memiliki bentuk cell heksagonal.

Berdasarkan data tersebut, untuk memenuhi kebutuhan traffic pengguna dan cakupan luas area, maka diperlukan minimum 205 base station femtocell dengan jumlah pengguna 183 orang per cell. Pada simulasi, lokasi pengguna akan terdistribusi secara seragam (uniformly distributed).

\section{B. Parameter Jaringan}

Simulasi jaringan femtocell 5G menggunakan parameter sistem yang tercantum pada Tabel 1.

\section{Pathloss}

Berdasarkan parameter jaringan femtocell pada Tabel 1, daya yang diterima di terminal pengguna dapat dihitung menggunakan penghitungan link budget (1). Setelah diketahui daya yang diterima dari terminal pengguna, rasio sinyal terhadap interferensi dan kebisingan (SINR) dapat diperoleh menggunakan persamaan (2). 
Tabel 1. Nilai Parameter Jaringan

\begin{tabular}{|c|c|}
\hline Parameter & Nilai \\
\hline Bandwidth sistem (MHz) & 20 \\
\hline $\begin{array}{c}\text { Frequency Carrier (GHz) } \\
\text { Daya Transmit Femtocell } \\
(\mathrm{dBm})\end{array}$ & 23 \\
\hline $\begin{array}{c}\text { Radius Femtocell Base } \\
\text { station }(\mathrm{m})\end{array}$ & 25 \\
\hline $\begin{array}{c}\text { Tinggi Femtocell Base } \\
\text { station }(\mathrm{m})\end{array}$ & 1,5 \\
\hline Noise floor $(\mathrm{dBm})$ & -174 \\
\hline
\end{tabular}

Gangguan dari pengguna $m$ dari pengguna lain ke-j dihitung dengan [6]:

$$
\Gamma_{m, j}=\sum_{m \neq j} P_{t} g_{j}
$$

\section{Beamforming}

Kami menerapkan teknik MRC beamforming yang diinisiasi oleh B. Ozbek dan U. Bayrak [9]. Vektor beamforming diperoleh dengan:

$$
\boldsymbol{w}_{\boldsymbol{k}}=\frac{\boldsymbol{h}_{\boldsymbol{k}}}{\left\|\boldsymbol{h}_{\boldsymbol{k}}\right\|}
$$

di mana $\boldsymbol{h}_{\boldsymbol{k}}$ adalah koefisien saluran mengikuti saluran Rayleigh antara femtocell dan terminal pengguna ke- $k$. Kemudian gain pada terminal pengguna dihitung dengan:

$$
G_{k, k}=\left|h_{k} w_{k}\right|^{2}
$$

Pada penelitian ini, beamforming melibatkan tiga skenario konfigurasi MIMO yang berbeda yaitu MIMO 4X4, MIMO 8X8, dan MIMO $16 \times 16$.

\section{HASIL DAN PEMBAHASAN}

Ilustrasi simulasi pada satu femtocell ditunjukkan pada Gambar 1. Hasil simulasi akan dianalisis melalui Cumulative Distribution Function (CDF) dari SINR dan datarate.

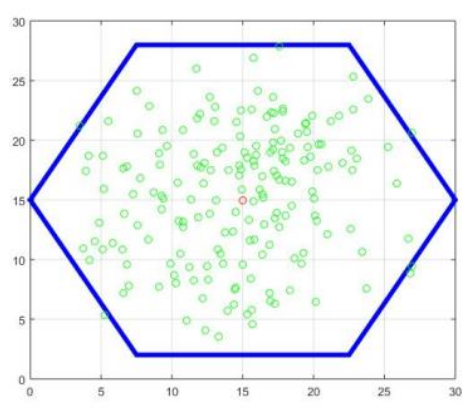

Gbr .1 Ilustrasi satu femtocell pada simulasi jaringan

\section{A. Pengukuran SINR}

Berdasarkan hasil simulasi yang ditunjukkan pada Gambar 2, untuk konfigurasi MIMO 4X4, 90\% pengguna memperoleh 10 $\mathrm{dBm} \leq \mathrm{SINR} \leq 29 \mathrm{dBm}$. Sedangkan pada konfigurasi MIMO 8X8, 90\% pengguna memperoleh $16 \mathrm{dBm} \leq \mathrm{SINR} \leq 40 \mathrm{dBm}$. Pada konfigurasi MIMO 16X16, 90\% pengguna memperoleh SINR $43 \mathrm{dBm} \leq \mathrm{SINR} \leq 70 \mathrm{dBm}$. Di antara tiga skenario beamforming yang digunakan, konfigurasi MIMO 16X16 menunjukkan SINR yang lebih baik dibandingkan dua konfigurasi lainnya.

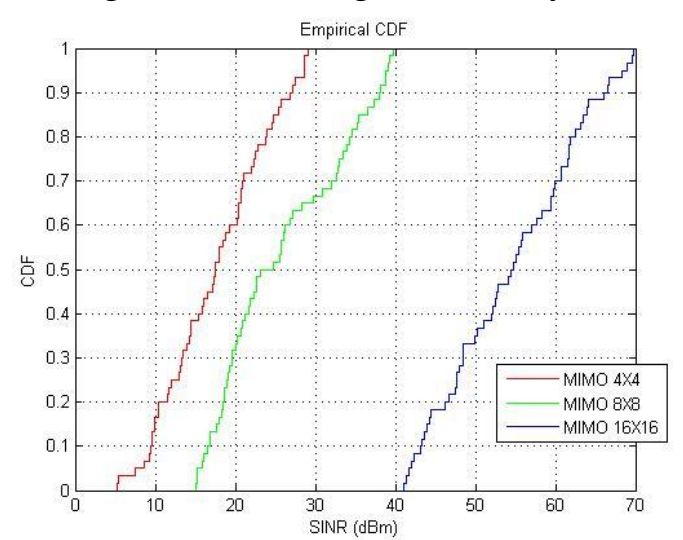

Gbr.2 CDF SINR Pengguna

\section{B. Pengukuran Datarate}

Hasil dari simulasi jaringan femtocell dengan tiga skenario MIMO direpresentasikan dalam bentuk datarate seperti yang ditunjukkan pada Gambar 3. Untuk mencapai standar karakteristik jaringan $5 \mathrm{G}$, pengguna harus mencapai setidaknya 1 Gbps [10]. Dengan konfigurasi MIMO 16X16, semua pengguna dapat mencapai setidaknya 1 Gbps. Dengan menggunakan MIMO 8X8, 30\% 
pengguna memperoleh target datarate $1 \mathrm{Gbps}$, sedangkan dalam konfigurasi MIMO 4X4, pengguna hanya dapat memperoleh datarate maksimum $0,8 \mathrm{Gbps}$.

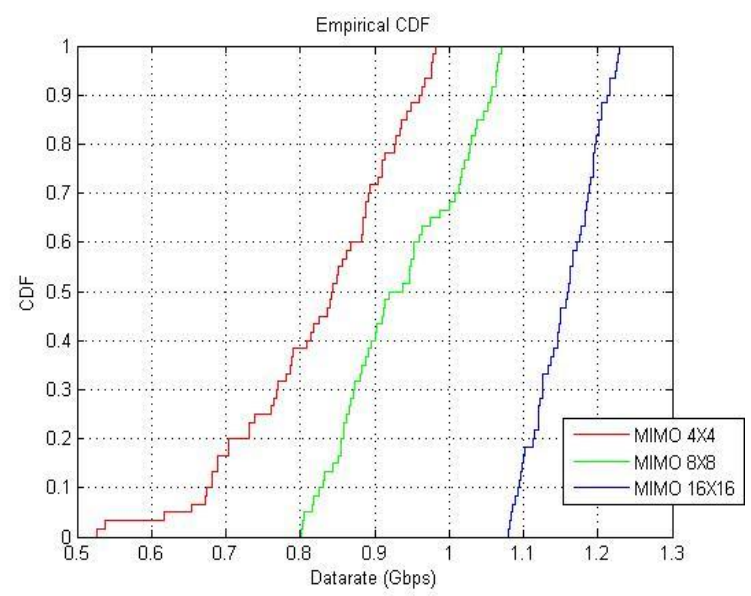

Gbr.3 CDF Darate Pengguna

Dengan konfigurasi MIMO 4X4, sistem beroperasi dengan performansi paling rendah daripada konfigurasi MIMO lainnya. Dengan menggunakan MIMO 8X8, distribusi kumulatif datarate pengguna sebagai salah satu parameter QoS (Quality of Service) meningkat karena semakin banyak stream yang disediakan selama jaringan beroperasi yang kemudian menghasilkan penguatan gain beamforming. Pada konfigurasi MIMO 16X16, sistem jaringan dapat menjamin semua pengguna untuk memperoleh setidaknya 1 Gbps sebagai karakteristik standar jaringan 5G, dan konfigurasi ini mengungguli konfigurasi MIMO lain yang disimulasikan dalam proyek ini.

\section{KESIMPULAN}

Teknologi 5G telah diprediksi mampu menyediakan layanan dengan standar yang lebih tinggi dibandingan generasi teknologi sebelumnya. Pada penelitian ini, kami melakukan analisis performansi melalui simulasi jaringan femtocell berbasis teknologi 5G. Jaringan femtocell menggunakan tiga skenario konfigurasi MIMO yang berbeda. Hasil simulasi menunjukkan bahwa dengan jaringan dengan konfigurasi MIMO 16X16, datarate yang diperoleh pengguna paling baik dibandingkan konfigurasi MIMO 8 X8 dan MIMO 4X4. Hal ini sesuai dengan semakin meningkatnya gain yang ditimbulkan dengan semakin banyaknya elemen antena yang digunakan pada teknologi beamforming.

\section{UCAPAN TERIMA KASIH}

Penelitian ini didanai oleh Penelitian Hibah Mandri 2018 Institut Teknologi Sumatera (ITERA). Penulis sangat berterima kasih kepada Lembaga Penelitian dan Pengembangan ITERA atas dikungannya sehingga penelitian ini dapat berjalan dengan baik.

\section{DAFTAR PUSTAKA}

[1] Rappaport, S. Theodore, Xing, Yunchou, MacCartney, Jr., George R., Molisch, Andreas F., Mellios, Evangelos, Zhang, Jianhua. "Overview of Millimeter Wave Communications for Fifth-Generation (5G) Wireless Network-with a focus on Propagation Models", IEEE Transaction on Antennas and Propagation, Special Issue on 5G, November, 2017.

[2] Bergren, Steven. Design Consideration for a $5 G$ Network Architecture.Oklahoma State University. 2017.

[3] Bjornson, Emil., Bengtsson, Mats., Ottersten, Bjorn., "Optimal Multiuser Transmit Beamforming: A Difficult Problem with a Simple Solution Structure," IEEE Signal Processing Magazine, Vol. 31, pp. 142-148, June 2014, DOI: 10.1109/MSP.2014.2312183

[4] Yoo, T., Goldsmith, A., "On The Optimality of Multiantenna Broadcast Schedulig using Zero Forcing Beamforming," IEEE Trans. Inf. Theory, vol. 49, no.3, pp. 528-541, March 2006.

[5] Jundhare, Mayuri D., Kulkarni, A. V., "An Overview and Current Development of Femtocells in 5G Technology," IEEE International Conference on Advances in Electronics, Communication and Computer Technology (ICAECCT), India, 
December 2016, DOI:

10.1109/ICAECCT.2016.7942583.

[6] Miao, Guowang, Zander, Jens, Sung, Ki Won, Slimane, Ben. Fundamental of Mobile Data Networks. Cambridge University Press. 2016.

[7] "Future Mobile Data Usage and Traffic Growth," Ericsson's Mobility Report, 2017

[8] Ghoul, Smail., Weijia, Jia., "Technoeconomic Analysis and Prediction for the Deployment of 5G Mobile Network," 2017, 20th Conference on Innovations in Clouds, Internet and Networks (ICIN), Paris, March 2017, DOI: 10.1109/ICIN.2017.7899243.

[9] Ozbek, Berna, Bayrak, Ugur., "Joint Beamforming and Power Control Technique for Femtocell Networks," Wireless Personal Communication, Vol. 95, pp. 4903-4916, August 2017, DOI: 10.1007/s11277-017-4131-5.

[10] Gemalto, "Introducing 5G Networks Characteristics and Usages," February, 2016. 